\title{
Leonid Brezhnev in Soviet Moldavia, 1950-52: the making of a GenSek? \\ Mark SANDLE, Igor CAȘU
}

\begin{abstract}
This is the first article dealing specifically with Brezhnev in Soviet Moldavia. The article draws mainly on recently disclosed files from the Archive of the Social-Political Organizations of the Republic of Moldova, the former archive of the Central Committee of Communist Party of Moldavia. The authors are trying to understand the importance of the period when Brezhnev served as First Secretary of Central Committee of Moldavia from 1950 to 1952 for his subsequent career. In order to understand better the results of Brezhnev's rule in Moldavian SSR and the impact on his leadership style, the authors discuss the previous career of Brezhnev as well as the activity of the previous First Secretaries in Soviet Moldavia. One of the main results of Brezhnev period in Moldavia was the consolidation of kolkhozes. In a broader sense, since this period at least, Brezhnev favoured quantity over quality.
\end{abstract}

Key-Words Brezhnev, Soviet Moldavia, Western Borderlands, Bessarabia, Transnistria, Nikolay Koval, collectivization, consolidation of kolkhozes

\section{Introduction}

Leonid Il'ich Brezhnev's rise to power has been somewhat understudied. He did in fact have a long and interesting journey - both politically and geographically - from Ukraine to Moscow and the unseating and removal of Khrushchev in 1964. This paper will explore the type of Republican Party leader he was, by examining in detail his time in Chișinău between July 1950 and October 1952 when he was head of the Communist Party of Moldavia (CPM), just prior to joining the Central Committee in Moscow after the $19^{\text {th }}$ VKP (b) Congress. A variety of sources - newspaper, archival (communist party and KGB) and memoir accounts - were consulted. His time in Moldavia was short and tends to get rather brushed over in the bigger story of his rise to power, given the extended amount of time he spent in Ukraine at Dnepropetrovsk and the importance of the so-called "Dnepro mafia" in subsequent events during Brezhnev's time as General Secretary. However, he became First Secretary of the Moldavian SSR (MSSR) at a critical moment in the consolidation of the rule of the CPM, and had to oversee some key developments in terms of agriculture, internal security, political organisation and ideology. Brezhnev was charged with twin tasks: completing the drive to Sovietise the Western republics of the USSR after the Great Patriotic War, and also implementing the postwar policy 
priorities of the centre as Stalin sought to reform the system. His leadership of the republic during these 26 months was sufficient for him to get the call to go to Moscow to join the new all-Union Central Committee at the $19^{\text {th }}$ Party Congress in 1952.

Brezhnev's tenure as First secretary of Soviet Moldavia was a key moment in his journey from provincial to national leader, for a number of reasons. Even though in some ways the MSSR was less important in terms of population and economic potential than Dnepropetrovsk, it was a politically significant move, as it placed Brezhnev at the level of being a republican party leader, ruling a whole national republic. This gave him the opportunity to be noticed by the key people in Moscow, to prove he was a reliable figure, able to implement the diktats of the centre, and so take the next step on the ladder. He also made significant political connections in Chişinău with individuals - notably Konstantin Chernenko, Nikolai Shchelokov, Sergei Trapeznikov and Semyon Tsvigun [his wife's brother-in-law] - who were very important in shaping elite politics within the CPSU, MVD and KGB after 1952 and right up until 1985. Studying Brezhnev's rule in Moldavia helps us to understand more about Brezhnev and his modus operandi. But analysing his time there also throws interesting light on what it means to be a party First Secretary in "late Stalinism", the pressures they were under and what was required to be deemed a successful Republican leader. Moreover, this study will illuminate something of the dynamics of late Stalinism itself, of the system on the eve of Stalin's death and the transition to the post-Stalin era.

\section{The Brezhnev "problem"}

The underreported story of Brezhnev's rise to power is part of a larger puzzle surrounding the life and times of Leonid Brezhnev. He remains something of a mystery. Brezhnev, up until recently, was deeply under-researched when compared to almost all the other Soviet leaders (save Andropov and Chernenko of course). This has always been something of a puzzle, given how long his tenure was and how much happened in the Soviet bloc during the period 196482 . So why has he been so forgotten and overlooked? ${ }^{1}$

1 The best review of the historiographical treatment of Brezhnev is Edwin Bacon, "Reconsidering Brezhnev", E. Bacon and M. Sandle, eds., Brezhnev Reconsidered, (Basingstoke, Palgrave 2002), 1-21. Otherwise, the authors of this article have not yet had the opportunity to examine Brezhnev's personal papers for this particular time period, or explore his tenure as First Secretary from the perspective of Moscow. See A.S. Stepanov, A.V. Korotkov, eds., Leonid Brezhnev. Rabochie i dnevnikovye zapisi, vol. 1-3 (Moscow: IstLit, 2016). 
Part of the answer is we believe to do with the timing of Brezhnev's tenure within the context of the longue durée of Soviet history. Brezhnev followed quickly after the colourful and quirky Khrushchev, and was followed rapidly by the momentous chaotic events of perestroika and Gorbachev and the collapse of communist rule. Scholars were, understandably, drawn to the sound and fury of The Collapse, or to the Great Patriotic War, or the 1930s or 1917. Brezhnev and his era - seemed somehow monochrome, insipid and frankly rather dull by comparison. Another reason for Brezhnev's marginalisation is that a consensus emerged fairly early on about the man and his tenure, and has proven to be remarkably resilient. The reforming discourse of the Gorbachev reign declared the Brezhnev years to be an "era of stagnation", and this discourse dominated the interpretations of the Brezhnev era for quite some time. Gorbachev's deployment of the stagnation thesis was clearly generated by the need to justify radical surgery to heal the ailing patient. But the end result was to "fix" a picture of Brezhnev - the ailing, decrepit leader presiding over a decaying superpower - in the minds of many. Finally we think that Brezhnev's marginalisation had something to do with a lack of source material too. ${ }^{2}$

Gradually though this is starting to change, although change is still slow and rather fitful. ${ }^{3}$ One of the sources for change has come from a growing realisation that the public opinion in post-Soviet Russia seem to reject the stagnation thesis, and instead identify Brezhnev as their most popular leader in the twentieth century. This "nostalgic turn" to Brezhnev began towards the end of the 1990s and the start of the 2000s, as Russia struggled with the turn towards marketization, and the "stable" Brezhnev years looked more and more like a "golden age" for your average Soviet worker and consumer. But even in the intervening period since the turn of the century, Brezhnev continues to be popular. Interestingly, the popularity also extends to Brezhnev as leader, not just the era of full employment, low prices, (slowly) improving living standards and global prominence. A May 1993 Levada Centre poll had Brezhnev at 56\% (positive feelings towards him) - beating Lenin at 55\%, Stalin at 50\%, Nicholas II at $48 \%$, Khrushchev at $45 \%$, Yeltsin (22\%) and Gorbachev (20\%). ${ }^{4}$ Another source of change is the emergence of new bodies of source material, notably a raft of memoirs and biographies. These came in two waves. In the early 1990s a large number of memoirs emerged from those who worked closely with him, or were associated with him. They give insights into his work style, personality,

2 Bacon and Sandle, Brezhnev Reconsidered, 1-21.

3 For a good overview see, Donald J. Raleigh, "Russia's Favourite", Russian Studies in History, vol. 52, 4 (2014), 3-11.

4 Raleigh, Russia's, 4. Bacon and Sandle also has some interesting polling data from the 1990s. 
habits, relations with subordinates and so on. A number of Russian biographies were published at this time, and they in essence maintained the stagnation thesis around Brezhnev. Later accounts and memoirs have sought - in line with the nostalgic turn - to emphasise stability and to provide a more rounded, sympathetic portrayal of Brezhnev. ${ }^{5} \mathrm{TV}$ documentaries and miniseries have added to the growing positive depictions of him. ${ }^{6}$ Academic treatments of Brezhnev remain frustratingly thin on the ground, for now. ${ }^{7}$ Outside of Bacon and Sandle (2002) and Thompson (2003), very little has been written until fairly recently. ${ }^{8}$ Work is now being done by a number of people on an academic biography, and on publishing his diaries/work notes by scholars at the German Historical Institute in Moscow and RGANI. Many more panels at conferences now include treatments of Brezhnev and his era, and so the signs look hopeful that he will no longer be the neglected leader of the USSR. ${ }^{9}$

5 Some notable biographies of Brezhnev include: Serguey Semanov, Brezhnev: pravitel' "zolotogo veka"' (Moscow: Veche, 2002); Aleksandr Maisuryan, Drugoi Brezhnev (Moskva: Vagrius, 2004); Leonid Mlechin, Brezhnev (Moskva: Molodaya Gvardiya, 2008); Aleksandr Khinshtein, Skazka o poteriannom vremeni. Pochemu Brezhnev ne smog stat' Putinym (Moscow, OlmaPress 2011). Among the plethora of memoir accounts, the following are worthy of note: E. Chazov, Zdorov'e i vlast': Vospominaniia "kremlevskogo vracha" (Moscow: Novosti 1992); V.T. Medvedev, Chelovek za spinoi (Moscow: Russlit, 1994); A.M. Aleksandrov-Agentov, Ot Kollontai do Gorbacheva (Moscow, Mezhdunarodnye otnosheniya 1994); Ljuba Brezhneva, The World I Left Behind (New York: Random House, 1995); A. Dobrynin, Sugubo doveritelno: Posol v Vashingtone pri shesti prezidentakh SSha (1962-86) (Moscow, 1997); V.V. Grishin, Ot Khrushcheva do Gorbacheva (Moscow: ASPOL, 1996); V. M. Sukhodrev, Iazyk moi - drug moi: Ot Khrushcheva do Gorbacheva (Moscow: AST-Olimp, 1999); V. Semichastnyi, Bespokoinoe serdtse (Moscow: Vagrius 2002); Aleksandr Bovin, XX vek kak zhizn', (Moscow: Zakharov, 2003); Iurii Churbanov, Moi test' Leonid Il'ich (Moscow: Algoritm, 2007); G. Arbatov, Moia epokha $v$ litsakh i sobytiiakh: Avtobiografiya na fone istoricheskikh sobytii (Moscow: Sobranie 2008); A.S. Cherniaev, Sovmestnyi iskhod: Dnevnik dvukh epoch 1972-1991 gody (Moscow: ROSSPEN, 2008).

6 Raleigh, Russia's, 10.

7 There were some early Russian treatments of Brezhnev. See for example, Iu. V. Aksyutin (ed.), L.I. Brezhnev: Materialy k biografii (Moscow: Politizdat, 1991); V.V. Sheludko (ed.), Leonid Brezhnev v vospominaniyakh, razmyshlenniyakh, suzhdeniyakh (Rostov-on-Don: Feniks, 1998).

8 William Tompson, The Soviet Union under Brezhnev (Harlow: Longman, 2003); Thomas Crump, Brezhnev and the Decline of the Soviet Union (New York: Routledge 2014); There have also been a number of works dealing with different aspects of the Brezhnev era, but not necessarily about Brezhnev himself.

9 Raleigh talks about these new developments, 4-6. Some early previews and commentary can be found in V. Donninghaus \& A. Savin, “The Brezhnev Era Through The General Secretary's Eyes, “'Don't Be Seen Repealing the Decree on the Jews - Just Don't Enforce It"; “Leonid Il'ich as Giver and Receiver"; "Leonid Brezhnev: Public Display Versus the Sacrality of Power", all published in Russian Studies in History, 52, 4 (2014): 12-18; 19-44; 45-70; 71-93. 
So the task remains for us to try and work to put together a more nuanced, rounded picture of Brezhnev, between the narratives of stagnation and stability, decay and nostalgia. This paper hopes to contribute to this by examining part of Brezhnev's rise to power, looking at his time in Chișinău.

\section{Brezhnev in Moldavia: Existing Accounts:}

Existing accounts of Brezhnev's time in Moldavia are relatively rare. The traditional Soviet account of a leader's rise to power can be found in Sovetskaya istoricheskaya entsiklopediya. ${ }^{10}$ This gives the usual brief biographical details, and Moldavia gets one line. There are three or four Russian biographies of Brezhnev which reference his move to Moldavia, but do not elaborate a great deal on his time there. ${ }^{11}$ Brezhnev himself in the Russian language version of his memoirs notes down some key moments from this time period. As one might expect from a memoir account it is full of enormous successes, of his satisfaction at the achievements he made in developing industry, improving agriculture and dealing with problems in the party. He hints at some of the problems he faced in the republic (although these are only really reported to show what an incredible job he did in transforming the republic in such a short space of time). ${ }^{12}$ But the acknowledgement of the complex issues he faced there is itself a revealing insight. A more critical view of Brezhnev's time in Moldavia comes from the memoirs of Ivan Ivanovich Bodiul (who was First Secretary of the CPM from May 1961 - December 1980). Bodiul accuses Brezhnev of failing to deal with the problems in Moldavia, and pursuing policies which were not in the interests of the republic. Instead he targeted measures and initiatives which made him look good in the eyes of the centre. His rule was based on making himself popular with his superiors. His policies did not deal with the real social and economic problems the Moldavians faced, and moreover even after he became GenSek, he failed to initiate any policies which actually favoured Moldavia. In short, according to Bodiul, Brezhnev used Moldavia to climb the ladder, and subsequently forgot all about her. ${ }^{13}$

The picture Bodiul tries to project of Brezhnev in Moldavia as First Secretary of the CC of CPM and his subsequent attitude toward the republic

${ }^{10}$ Various, Sovetskaya istoricheskaya entsiklopediya (Moskva: Gosudarstvennoe nauchnoe izdatel'stvo, 1962), 711.

${ }^{11}$ See for example Semanov, Brezhnev; Maisuryan, Drugoi Brezhnev; Mlechin, Brezhnev. Maisuryan's work, for example, has only 3-4 pages, which includes the rather mythologised account of the first encounter between Brezhnev and Stalin, Maisuryan, Drugoi Brezhnev, 9-102.

${ }^{12}$ L.I. Brezhnev, Vospominaniya (Moskva: Izdatel'stvo politicheskoi literaturyi 1983) ch. 5. The English language versions of Brezhnev's memoirs actually skip over his time there completely.

${ }^{13}$ I.I. Bodiul, Dorogoi zhizni (Chișinău: KUSHIR i Co., 2001), 51-61. 
is not very accurate. On the contrary, the archival data seems to contradict Bodiul, especially related to Brezhnev's attitude toward Moldavia after 1964, as the Chişinău authorities in many cases received preferential treatment and investment from Moscow. For instance, in 1971 the Council of Ministers of the USSR jointly with the CC CPSU adopted a special decision on 'Measures for the development of Chișinău' which meant huge investment in the infrastructure, the Moldavian capital being the first among the federal republics to receive preferential funds in this regard. ${ }^{14}$ Given how the system worked, without Brezhnev's intervention and support, this could not have happened. Bodiul also received preferential funds for Moldavian agriculture and during the late 1960s and early 1970s at least, it seemed that MSSR became a model for how Soviet agriculture should develop in order to become efficient. ${ }^{15}$ It seems that Bodiul intentionally tried (he died at age 95 in January 2013) to downplay the role of Brezhnev and thus exaggerate his own merits as First Secretary of Moldavia from 1961 to 1980 and project himself as a kind of "founding father" of presentday Moldova. ${ }^{16}$

Another post-Soviet Moldavian account on Brezhnev in MSSR has been published in 2012 in Chișinău by Gheorghe Gorincioi, a former dean of the Journalism Department at Chişinău State University and subsequently an instructor at the CC of CPM in the 1980s. His book is more of a compilation of the already published information about the Brezhnev years in Moldavia than an original empirical contribution to the topic. It is important however in the sense he brings a different perspective, one which contradicts the views of Bodiul. Gorincioi depicts Brezhnev in Moldavia as a strong leader, trying to introduce a new style of government, more open to the people and encouraging the personnel of the CC of PCM to greet each other and to be nicer than with previous First Secretaries. The author also stresses the fact Brezhnev helped a lot of people that he knew in Moldavia. He cites the example of Victor Golikov, a CPM instructor in Soroca rayon in northern MSSR (1948-1956). Golikov was from 1956 to 1982 the personal adviser of Brezhnev. Gorincioi notes that after leaving Moldavia, Brezhnev helped his local Moldavian friends when they lost their prestigious jobs during the Bodiul reign (1961-1980). In the cases

${ }^{14}$ See AOSPRM [Arhiva Organizațiilor Social-Politice a Republicii Moldova], F. 51, inv. 32, d. 22, ff. 7-26; for other funds request sent by Bodiul directly to Brezhnev, see also F. 51, inv. 33, d. 83, ff. 77-79; d. 81, ff. 17-18.

${ }^{15}$ AOSPRM, F. 51, inv. 33, d. 81, ff. 57-73; d. 82, ff. 57-59.

16 "Moldavia" was the consecrated Russian name given to the Soviet republic, but in fact "Moldavia" has Latin roots, see for instance, Demetrius Cantemir, Descriptio antiqui et hodierni status Moldaviae (Frankfurt, Leipzig:1771). It was changed to Moldova on gaining independence in 1991, which is the native Romanian name for the Latin and Russian "Moldavia". 
of Artem Lazarev, (his minister of Culture) and Gherasim Rudi (his prime minister), when both were marginalized by Bodiul in the 1970s, Brezhnev intervened and both became rectors of the two prestigious Moldavian higher education institutions. Moreover, Brezhnev made important contributions to the development of the Burevestnik republican football team and attended the main matches. While Secretary General of CC CPSU, Brezhnev helped Soviet Moldavia a lot, and visited it many times, concludes Gorincioi. ${ }^{17}$ Another recent account of Brezhnev in Moldavia is that of one of the most important Moldovan historians, Valeriu Pasat. Pasat explores Soviet Moldavia from 1940 to 1953, and includes some discussions of Brezhnev's time. Among the new data from the Moscow archives about Brezhnev in Moldavia disclosed by Pasat, is the fact that he patronized local corruption networks, especially the one in which his chief of government, Gherasim Rudi, was involved. Pasat highlights how Brezhnev was a great rewarder of loyalty amongst his subordinates and colleagues, overlooking any "problems" in their work. This reinforces the picture painted by Gorincioi. ${ }^{18}$

English language works offer similarly scant accounts of his time there. English language histories of Moldavia say little about Brezhnev himself, focusing instead on the socio-economic and cultural aspects of the early postwar years. ${ }^{19}$ The main recent works on Brezhnev (be they political biographies or more general works on his era as GenSek) do not really deal with his rise to power in any great detail, and besides Brezhnev still awaits a biographical treatment on the scale of those given to Lenin, Stalin, Khrushchev and Gorbachev, which in itself is something of a puzzle. ${ }^{20}$ Dmitri Volkogonov in his portraits of the seven Soviet leaders devotes 3 pages or so to his time in Moldavia. Volkogonov paints Brezhnev as a middle-ranking Party functionary and an intellectual mediocrity, who enjoyed the privileges that went with being a Republican party leader. He does attest though to Brezhnev's energy

${ }^{17}$ Gheorghe Gorincioi, RSS Moldovenească de la Leonid Brejnev la Ivan Bodiul. Cronică despre epocă și oameni (Chișinău: Notograf Prim, 2012).

${ }^{18}$ Valeriu Pasat, RSS Moldovenească în perioda stalinistă, 1940-1953 (Chișinău: Editura Cartier, 2011), 178-179.

${ }^{19}$ See for example, Michael Bruchis, One Step Back, Two Steps Forward: On the Language Policy of the Communist Party of the Soviet Union in the National Republics (Moldavian: a Look Back, a survey, and perspective, 1924-1980), (Boulder, Co.: East European Monographs, 1982); Charles King, The Moldovans: Romania, Russia and the Politics of Culture (Stanford: Hoover Institution Press, 2000). M. Gribincea, Agricultural Collectivisation in Moldavia (New York: Columbia University Press, 1996).

${ }^{20}$ This should be changing though. A number of scholars appear to be working on biographies of Brezhnev at present, e.g. Donald Raleigh and Susanne Schattenberg. 
and zeal in tackling the tasks of collectivisation, industrial development and ideological reform. ${ }^{21}$ The fullest English language account is probably still that of the journalist John Dornberg whose work Brezhnev: Masks of Power was published in 1974..$^{22}$ Dornberg's appraisal offers an interesting counterpoint to Volkogonov, especially given the fact that Dornberg wrote his book while Brezhnev was still at the peak of his powers, and had not slipped into the physical and political torpor of his latter years. Dornberg notes that Brezhnev's rise to power up until his assignment to Chișinău was due to his ability to carry out party decisions clearly and efficiently and his breadth of experience - industry and agriculture, party and government. He emerges from Dornberg's book as a cautious, pragmatic figure, a realist who took few chances on his way up. $\mathrm{He}$ also seemed to be Moscow's choice in the aftermath of a purge, clearly viewed as a steady hand at the helm. During his time in Moldavia though Dornberg argues that Brezhnev was actually fairly draconian in his approach to governing the republic. He "completed" collectivisation, carried out purges against the nationalist intelligentsia, built up the party organisation and membership, and improved ideological and propaganda work. He also undertook a sustained construction campaign in Chişinău itself. ${ }^{23}$

Another pre-perestroika account can be found in Paul Murphy, Brezhnev: Soviet Politician (1981). Murphy paints a portrait of Brezhnev as a ruthless, strong and determined leader who was caught up in the struggle for power between Khrushchev and Malenkov in the latter years of Stalin's rule. Murphy points to the deep political connections between Brezhnev and Khrushchev which lay behind the decision to send Brezhnev to Chișinău. His chapter on Moldavia points out the speed at which he undertook change, and also the draconian way in which he wielded power, notably his purge of the collective farm sector and his moves to liquidate all opposition to Soviet rule, especially in the western part of Moldavia. Murphy also emphasises Brezhnev's work in the area of media and culture, and the controversy which surrounded his departure in the summer of 1952, when he appeared to be the victim of a campaign from Moscow orchestrated by Malenkov in his struggle with Khrushchev. ${ }^{24}$

So, we know very little of Brezhnev in Moldavia. Before we explore his time in office there, a little contextualisation is required.

${ }^{21}$ D. Volkogonov, Autopsy for An Empire (New York: The Free Press, 1998), ch. 4.

${ }^{22}$ J. Dornberg, Brezhnev: The Masks of Power (New York: Basic Books, 1974) ch. 7.

${ }^{23}$ Dornberg, Brezhnev, 108-13.

${ }^{24}$ One of the frustrations of Murphy's chapter is that there are no references for some of the points he makes about Brezhnev, so it is very difficult to verify much of what he is saying. See Paul J. Murphy, Brezhnev: Soviet Politician (Jefferson, N.C.: McFarland, 1981). 


\section{Context: Moldavia before 1950}

Soviet Moldavia was a new addition to the USSR, emerging out of the complex frontier changes of the interwar and wartime period. In the process of being "Sovietised" after 1944 (in similar fashion to the Baltic States) a number of issues came to the fore which featured prominently during the period 1950-52. The first issue was national identity and language policy. The second issue was cadre policy, in particular the ethnic and political background of the new elites. The third issue was collectivisation and the Soviet take-over of the Moldavian countryside. The final one was the deportations and removal of anti-Soviet elements, including so-called kulaks, nationalists and Jehovah's Witnesses. Let us turn first to the question of national identity and language policy in the new republic.

An autonomous Moldavian republic was founded on October $12^{\text {th }} 1924$ within the boundaries of Soviet Ukraine. In the interwar period, the Soviet Union continually laid claim to Bessarabia. But the assertion of a separate Moldavian national identity was not promoted coherently before 1940. For instance in the first Soviet census in 1926, Moldavians and Romanians were included in the same nationality category. In 1924-1932, the Russian script was the official one in the MASSR for the titular nationality, Moldavians/ ethnic Romanians. Between 1932 and 1938 the adoption of literary Romanian and the introduction of Latin letters were promoted at the official level in the Moldavian ASSR. However, in 1938, this decision was reversed and the Cyrillic script was reintroduced into the MASSR. This was accompanied by purges of cultural figures during the "Great Terror" of $1938^{25}$.

As a result of the Molotov-Ribbentrop pact a Moldavian Soviet Socialist Republic was created on August 21940 out of parts of former MASSR and 2/3 of Bessarabia. This lasted up until Operation Barbarossa, when Bessarabia became again part of Romania as in the interwar. In 1944 the Soviets re-occupied the Romanian province of Bessarabia and re-created the MSSR. The question of language and national identity was to surface again after 1944, especially amongst the literary and cultural intelligentsia who wished to use both the Romanian language and the classical Moldavian literary canon to promote a Moldavian national identity. The linguistic policy pursued between 1940 and 1941 and after 1944 (stemming from the approach of 1924-1932 and 1938-1940 in MASSR) aimed at transforming the Moldavian idiom into a Slavic language,

${ }^{25}$ See more on that in Igor Cașu, „The Fate of Stalinist Victims in Moldavia after 1953: Amnesty, Pardon and the Long Road the Rehabilitation", in Kevin McDermott and Matthew Stibbe, eds., De-Stalinising Eastern Europe. The Rehabilitation of Stalin's Victims after 1953,. (Houndmills, Basingstoke: Palgrave Macmillan, 2015), 189-190. 
removing any linkages with Romanian, and thereby creating an independent Moldavian national language. ${ }^{26}$ Closely related to the issue of national identity and language policy was the question of cadre policy. The problem here related to elite recruitment and relations between Chișinău and Moscow, and originated from the interwar period too. Moscow looked with suspicion upon the Bessarabian communists (i.e. members of the interwar Bessarabia section of the Communist Party of Romania). Within the MASSR itself (1924-1940), there were very few communists amongst the Romanian-speaking population. This led to Moscow inexorably favoring the Russian, Ukrainian or Moldavian deeply Russified groupings from within the MASSR. In June 1940 Bessarabia entered the Soviet zone of influence according to the Stalin-Hitler Pact of 1939. At this point the Bessarabian communist grouping numbered 300 members, but they were viewed with deep suspicion by Moscow, as anyone both living in a bourgeois society and residing abroad, was suspected of having been flirting with the "class enemy". Thus, the leading role in the MSSR in this period was assigned to the Transdniestrian elites, who were trusted because they had been socialised in the Soviet Union during the interwar period. From June 28 to August 2 1940, Bessarabia was incorporated into the Moldavian ASSR, i.e. it became a part of Soviet Ukraine. On 2 August 1940, the new Moldavian Soviet Socialist Republic was formed (MSSR). Piotr Borodin (Russian, born in 1905 in Dnepropetrovsk) ${ }^{27}$, the former first secretary of the Moldavian regional committee of Communist (Bolshevik) Party of Ukraine from June 1939 was named as First Secretary of the newly-created Moldavian SSR on 14 August 1940 , i.e. about two weeks after the official formation of the MSSR.

The experiences of the CPM First Secretaries between 1940 and 1950 are also crucial for understanding the challenges faced by Brezhnev. The shaping of the territorial boundaries of the new republic came about as a result of complex interactions between Chișinău, Kiev and Moscow. In order to secure their western frontier, Moscow was looking for compliance from the CPM. But Ukraine also continued to exercise a great deal of influence over events in Moldavia. Nikita Salogor (Moldavian/Romanian, born in 1901 in the Odessa region $)^{28}$ became First Secretary on September 7 1942, seemingly because it was believed that he would be more compliant and less demanding than Borodin. ${ }^{29}$

\footnotetext{
${ }^{26}$ Michael Bruchis, One Step Back, Two Steps Forward: On the Language Policy of the Communist Party of the Soviet Union in the National Republics (Moldavian: a Look Back, a survey, and perspective, 1924-1980) (Boulder, Co.: East European Monographs, 1982), 71-148.

${ }^{27}$ AOSPRM, F. 51, inv. 1, d. 32, f. 5.

${ }^{28}$ AOSPRM, F. 51, inv. 1, d. 32, f. 15.

${ }^{29}$ AOSPRM, F. 51, inv. 1, d. 80, f. 2.
} 
Very few requests were sent up to Moscow from Chișinău between 1940 and 1946. One of the most important and controversial documents sent by Salogor to Stalin was a 48 page memo dated June $261946 . .^{30}$ This was a politically sensitive issue. The first part of the memo was related to the revision of the frontiers with Ukraine in the sense of including in MSSR all the Bessarabian territories (about $1 / 3$ of historical Bessarabia in the south and a small part in the north which had gone to Ukraine in August-November 1940, which meant that the MSSR lacked direct access to the Danube estuary and the Black Sea). This part of the memo was signed by Salogor and even though it also included the name of Nikolay Koval, the Chairman of the Council of Ministers of MSSR, his signature was not on the paper. The second part of the memo expressed the wish to extend the frontier of the MSSR, this time at the expense of Romania, as the idea was to include in Soviet Moldavia all the historical lands of the medieval state of Moldavia, i.e. the territory between the River Prut and the Carpathian mountains. This part of the memo was related to the Paris Peace Conference and was signed by Fiodor Brovko (a Transdniestrian Moldavian/ Romanian, member of the establishment of MASSR). What is important in the context of cadres' policy in Soviet Moldavia and especially the centre-periphery relations in this regard is that the leader that signed the first part of the memo, Salogor, was demoted from his post in less than a month, on July 18 1946, but Brovko preserved his post until 1951. One can thus speculate that the idea to revise the frontiers with Ukraine was more unacceptable and dangerous for Moscow than the idea of revising the border with Romania. It seems likely that Khrushchev, then the first secretary of CC of $\mathrm{CP}(\mathrm{b})$ of Ukraine may well have insisted on the demotion of Salogor, his former subordinate before 1940 when Salogor worked in the leadership of Moldavian regional committee (MASSR). This seems plausible because Khrushchev was personally involved in drawing the frontiers of MSSR in August-November 1940 in his capacity as chairman of the respective commission as well as in his double post of first secretary of CC of CP (b) of Ukraine and secretary of All-Union CC of CP (b) ${ }^{31}$. Moreover, Khrushchev had already attempted to increase the territory of Ukraine at

${ }^{30}$ AOSPRM, F. 51, inv. 4, d. 64, ff. 1-48.

${ }^{31}$ See more on the 1946 memo to Stalin, Igor Cașu and Virgil Pâslariuc, "Moldavian SSR's Border Revision Question: From The Project of „Greater Moldavia” to The Project of “Greater Bessarabia” and The Causes of their Failure (December 1943 - June 1946)" (Documents in original Russian, translated in Romanian, with Introduction article of 22 pages, English summary), Archiva Moldaviae, 2, 2010, 275-370. 
the expense of Belorussia and he did not seem to have any scruples about manipulating ethnographic data and historical maps. ${ }^{32}$

The next first secretary of CC of CP (b) M after the demotion of Salogor on July 181946 was Nikolay Koval, also a Moldavian/Romanian from the MASSR interwar establishment, and the person who did not sign the memo to Stalin requesting the revision of the frontiers with Ukraine. He was in turn very cautious, not daring to ask for more help from Moscow during the famine of 1946-1947, a tragedy which cost around 120000 lives in less than a year in the MSSR alone (out of the total population of 2.5 million) ${ }^{33}$. In 1950 he was made responsible for failing to show sufficient zeal against the "enemies of the people' (kulaks, nationalists and religious groups) ${ }^{34}$ and was replaced by Leonid Brezhnev on July 6 of that year. It seems that the latter was named by Stalin directly. Clearly Moscow believed it was vital, during the early years of Sovietization, to ensure the loyalty of the new leadership, hence their reluctance to appoint anyone from the Bessarabian group, and their willingness to intervene closely to ensure compliance.

Thus the circumstances in which Brezhnev took over were not particularly easy. Moldavia was in the throes of multiple transitions as the VKP (b) began the process of Sovietizing the republic in the aftermath of WWII and the Nazi occupation, in line with the other parts of the Soviet West, notably the Baltic republics. Embedding Soviet-style rule meant a number of things, but primarily these involved the collectivisation of Moldavian agriculture, the suppression of manifestations of local nationalism (and other forms of opposition), consolidating the position of the party and its personnel, responding to the central diktats of Moscow and integrating the Moldavian economy with the All-Union economy. The drive for total collectivization began after August 1947 when only 154 collective farms existed. In order to speed this process up, coercive measures started to be adopted between 1947 and 1949, including the forcible socialisation of property, and broadening the criteria for a "kulak" in order to force people to join, or be excluded/deported. After the mass deportations of 1949, there was a rapid increase in applications to join the collective farms. By 1 July 1949, 965 collective farms had been created. But Sovietization Moldavian style had also produced mass arrests and deportations:

${ }^{32}$ Politicheskoe rukovodstvo Ukrainy, 1938-1989, pod redaktsiei V. Iu. Vasil'eva, R. Iu. Podkura, Kh. Kuromya, A. Weinera (Moscow: ROSSPEN, 2006), 65-66.

${ }^{33}$ On the 1946-47 famine in MSSR, see Igor Caşu, Dușmanul de clasă. Represiuni politice, violență și rezistență în R(A)SS Moldovenească, 1924-1956, second edition (Chișinău: Cartier, 2015), 189233.

${ }^{34}$ See more in AOSPRM, F. 51, inv. 9, d. 3. 
on 12-13 June 1941 and 5-6 July 1949, (accounting from MSSR alone for 18,392 and 35,796 deportees respectively). ${ }^{35}$ The CPM was also still trying to ensure the reliability of its cadres, as the usual suspicion of wartime communist activity was mixed with concerns over the ethnic basis of CP elite recruitment. It was into this situation that Brezhnev appeared on 5 July 1950. The choice of Brezhnev for this assignment was clearly recognition by his superiors that he had the wherewithal to deal with the complex issues within the republic, issues which required decisive and rapid action.

\section{Moldavia and Late Stalinism}

Brezhnev's time in Moldavia needs to be understood also within the context of broader developments within the USSR after 1945. This adds a further layer of complexity to the tasks facing Brezhnev. Not only did he have to complete the Sovietisation of Moldavia, he also had to respond to the priorities and diktats of the regime after 1945. Soviet Moldavia was thus undergoing Sovietisation and re-Stalinisation simultaneously. This period of "late" Stalinism or postwar Stalinism has been increasingly scrutinised by scholars in recent years. ${ }^{36}$ This is clearly a highly complex era, distinct from both the 1930s and the war years. The imperatives of this era were fourfold. Alongside the drive for material and economic reconstruction, and the search for international security and military strength, the postwar years were also an attempt to restore order and control (after the relative "freedoms" of the war years), and also to begin looking to the future and the building of communism. This was, as has been noted, the "Relaunch of the Soviet Project" after the trauma and hiatus of 4 years of war. ${ }^{37}$ The challenge was how to embark upon the restoration of control and

${ }^{35}$ I. Cașu, "Stalinist Terror in Soviet Moldavia, 1940-1953, in Kevin McDermott and Matthew Stibbe, eds., Stalinist Terror in Eastern Europe, (Manchester: MUP, 2010), 39-56.

${ }^{36}$ See for example: E. Zubkova, Russia After the War (Armonk, NY: M.E. Sharpe 1998); Amir Weiner, Making Sense of War: The Second World War and the Fate of the Bolshevik Revolution (Princeton: Princeton University Press, 2000); Amir Weiner, ed., Landscaping the Human Garden (Stanford: Stanford University Press, 2003); "The Empires Pay a Visit: When Gulag Returnees Encountered East European Rebellions on the Soviet Western Frontier," Journal of Modern History 78:2 (2006); Sheila Fitzpatrick, "Late Stalinism in Historical Perspective" in Late Stalinist Russia: Society between Reconstruction and Reinvention edited by Julianne Furst, (New York: Routledge, 2006), 411-434; Mark Harrison, “The Soviet Union After 1945: Economic Recovery and Political Repression”, Past \& Present 210, 6 (2011), 29-46. For some comparative insights see Kees Boterbloem, Life and Death under Stalin: Kalinin Province 1945-53 (Montreal: McGill-Queen's University Press, 1999); Romuald Misiunas and Rein Taagepera, The Baltic States: Years of Dependence 1940-90 (London: Hurst and Company 1993).

37 “The Relaunch of the Soviet Project, 1945-64”, Slavonic and East European Review, 86, 2 (2008), Special Issue. 
the reconstruction of the material basis, whilst also setting out to construct communism. Reasserting control required the elimination of those elements deemed to be dangerous and subversive. The new society also required the elimination of those elements deemed to be unworthy of membership in the new society. Both the immediate and the long-term required the state to resolve questions of inclusion and exclusion: who was to be part of the new Soviet people? Postwar purification of the Soviet Union now had two main criteria by which to judge questions of inclusion and exclusion: wartime conduct and ethnicity and/or religion. ${ }^{38}$ The project of creating a new Soviet people was fraught with problems.

\section{Brezhnev before 1950:}

Brezhnev's time in Chișinău has to be seen against the backdrop of his own political journey too. A metallurgical engineer by training, he joined the communist party in Kamenskoye (later Dneprprodzerzhinsk) in 1931, and first crossed paths with Khrushchev in 1938, and in that same year he was appointed to the party apparatus in Dnepropetrovsk, a major industrial city. He joined the army in August 1941, and was an active participant in the fight against Nazism. After the war, his promotions continued, although his path up the ladder was complicated by the political infighting at the elite level. Part of Khrushchev's entourage, Brezhnev was sent to Zaporozhye in August 1946 to help Khrushchev in the fight against Ukrainian nationalism, and to purge the party machine. Brezhnev came under significant pressure from Zhdanov and others to increase the pace of reconstruction in Zaporozhye in 1947 and to demonstrate some tangible achievements. He seemed to respond well to this challenge and by in November 1947 - as a result of a purge of the party leadership - Brezhnev was sent to Dnepropetrovsk to be head of the party, and was soon co-opted into the CC of the Ukrainian communist party, serving alongside Khrushchev. When Khrushchev left Kiev in December 1949, he took Brezhnev with him. There was a short sojourn in Moscow before he was sent to Chișinău to become a republican party head for the first time.

As First Secretary of the new Soviet republic of Moldavia, Brezhnev was faced with complex problems. He was responsible for the implementation of a range of central directives and policies coming down from Moscow. The postwar drive to restore order, clampdown on dissent and reassert control of

${ }^{38}$ See Weiner, Making Sense of War; and Landscaping; Harrison, The Soviet Union After 1945; Fitzpatrick, Late Stalinism. For a more recent and authoritative argument on this issue, see David Shearer, Policing Stalin's Socialism. Repression and Social Order in the Soviet Union, 19241953 (New Haven: Yale University Press; Stanford: Hoover Institution Press, 2009). 
the countryside was strengthened at the All-Union level from 1949 onwards, as a wave of repressions and purges were unleashed. Campaigns against religious belief and practice were inaugurated. A constant theme was the need to improve agitation and propaganda work within party and society. Moves to strengthen party control of the countryside (whilst at the same time working to increase agricultural productivity) led to the May 1950 decree on amalgamating kolkhozes. The situation in the western borderlands was especially sensitive. The recent history of wartime occupation, collaboration and resistance continued to cast a shadow over public life. The issues of ethnicity and language were deeply contentious. Now as the USSR sought to solidify its position in controlling the new socialist bloc that was emerging, tackling any outbreaks of dissent (especially that with the hue of bourgeois nationalism) was seen as particularly critical. The example of Estonia in March 1950 where the Politburo began a purge of the party and state structures through a resolution entitled "On the shortcomings and mistakes in party work in Estonia" was a foretaste of events in Moldavia just 4 months later. ${ }^{39}$ To begin, let's examine the take-over of power in July 1950.

\section{The Take-Over: Brezhnev at the helm}

Brezhnev was the first person after the Second World War from outside the establishment of the Moldavian Autonomous Republic (1924-1940) to run the republic. Pasat notes that the appointment of Brezhnev in MSSR in 1950 coincided with the decision of Moscow to end the institute of special envoy of $\mathrm{CC} \mathrm{VKP}(\mathrm{b})$ in Moldavia and gave more authority to the local republican leadership. ${ }^{40}$ The reasons why Brezhnev was appointed as First Secretary of the CPM can be understood a little more by examining the report summarizing the activity of his predecessor, Nikolay Grigoryevich Koval. The report dates from April 181950 and was elaborated by Mikhail Turkin, the special representative of the CC VKP (b) to Moldavia, and it entailed a substantial critique. The first set of allegations against Koval referred to 'formalism'. According to Turkin, at least 14 raion and city party organizations did not even discuss, let alone implement, $70 \%$ of the total orders and decisions made by the CC CPM. This was due to the fact that Koval made few visits outside Chișinău and tended to avoid meetings with his direct subalterns from the Secretariat of the CC. Koval was also targeted for protecting some high officials involved in stealing huge sums from the state budget, infringements on 'socialist legality', as well as falsification of documents and official reports. A more serious case was that the

\footnotetext{
${ }^{39}$ Zubkova, Russia, 134.

${ }^{40}$ Pasat, RSS Moldovenească, 176.
} 
Minister of the Timber and Paper Industry of MSSR, who was the leader of a mafia network and had also used physical violence against his subalterns. ${ }^{41}$

Another category of problems was related to Koval's inability to prevent the appointment and removal of around 60 persons belonging presumably to the category 'enemies of the people'. The great bulk of these cadres were involved in Higher Education institutions, in the mass-media, and publishing houses. For instance, according to Turkin's report sent to Moscow, in the Institute of Medicine, there were working former White Guard officers evacuated after 1918 in Bessarabia (a part of Romania till 1940), as well as former repressed persons. At the Pedagogical Institute in Bălți, a similar situation was reported, except this time these 'enemies of the people' were being protected presumably by Artem Lazarev, the Ministry of Education of MSSR, himself a protégé of Koval. At the Pedagogical Institute in Chișinău, Romanian translations published in Bucharest of the classics of Marxism-Leninism were preferred instead of the Russian versions, arousing suspicion of nationalist sympathies. In Turkin's opinion, Koval did not fight sufficiently against other manifestations of Moldo-Romanian and Jewish nationalism..$^{42}$ Even though some of the persons mentioned were removed or punished, this was done as a result of pressure from Moscow and not as an outcome of the local initiative. So, one could conclude the centre lost its trust in the former MASSR establishment and decided to name somebody not connected with the local elite networks and groups of interests. Given the sensitivity in Moscow to manifestations of nationalism in the Western borderlands, Koval's "shortcomings" must have been ringing alarm bells.

As with his previous appointment as oblast party chief in Dnepropetrovsk in November 1947, Brezhnev was appointed (it seems under the patronage of Nikita Sergeevich Khrushchev ${ }^{43}$ ) as party chief in Moldavia in July 1950 as a result of the removal of Koval. ${ }^{44}$ The All-Union CC issued a decree on 5 June 1950 which accused Koval of a number of problems, but the tone was

${ }^{41}$ AOSPRM, F. 51, inv. 9, d. 3, ff. 92-111.

${ }^{42}$ AOSPRM, F. 51, inv. 9, d. 3, ff. 92-111

${ }^{43}$ Leonid Mlechin, Brezhnev, (Moskva: Prospekt, 2005), 72. The version expressed by the wife of Brezhnev that her husband met personally with Stalin in 1950 before coming to Moldavia is not supported by documents. Serguei Semanov, Brezhnev: pravitel' "zolotogo veka" (Moscow: Veche, 2002), 25. Cf. A. A. Chernobaev, ed., Na prieme u Stalina. Tetradi (zhurnaly) zapisei lits, prineatykh I. V. Stalinym (1924-1953). Spravochnik (Moskva: Novyi Khronograf, 2008), 528538. Brezhnev never personally met Stalin even after being selected by him for the Presidium of CC of CPSU in October 1952. He did however meet him several times in group meetings. Chernobaev, Na prieme, 545-554.

${ }^{44}$ See Bodiul, Dorogoi zhizni, 50; Dornberg, Brezhnev, 108. 
downplayed as compared to the incriminations put forward in April 1950 by Turkin, Moscow's representative in Moldavia. ${ }^{45}$ In part this was because this decree linked Koval's shortcomings, with the diktats and priorities of the Centre. This decree set the tone for the first part of Brezhnev's time in Moldavia. His task was simple: to resolve the issues identified within the CC resolution. What did they identify as being the main shortcomings in the work of the Moldavian CC?

The 5 June decree mentioned the following issues as being problematic: Failing to accelerate the socialisation of agriculture, defective ideological work (in particular permitting bourgeois nationalist distortions in Moldavian literature), and paying insufficient attention to the training of student youth and the educational role of schools in the weakly controlled areas. It went on to note the low numbers of communists in villages, the dearth of rural party organisations and outlined severe criticisms of the poor preparation for the harvest. It concluded by identifying a series of problems around socialist legality. ${ }^{46}$ In sum, the central leadership were concerned at three main things: the state of agriculture, local nationalism, and the party itself, its membership, structure and operation. In the discussions at the 5-6 July 1950 CC PCM meeting, Brezhnev reported that there was "full support" for this CC resolution, as well as "strict criticism" of the First Secretary and members of the CC CPM buro. ${ }^{47}$ Koval was removed as First Secretary, and Brezhnev assumed the hot seat.

Brezhnev's time in Moldavia was something of a whirlwind of activity. $\mathrm{He}$ arrived in July in the midst of a storm, as Moscow was denouncing the current leadership for some "deficiencies" in their activities. There followed a rapid series of initiatives, discussions and reforms. He oversaw 2 CPM Congresses ( $3^{\text {rd }}$ Congress in March 1951 and $4^{\text {th }}$ in September 1952). There were 11 party plenums in this period (including the initial one where he took over) although he missed the June and July 1952 plenums through serious illness and his subsequent recuperation. He presided over the $10^{\text {th }}$ anniversary celebrations of the formation of the MSSR on 2 August 1940. He organised various republican level meetings of propaganda workers (November 1950) and party activists (February 1952). It is noticeable from examining the speeches made by Brezhnev at the CC CPM plenums, that generally Brezhnev devoted his time to 2 areas: the problems and policies of the agricultural sector, especially of the kolkhozes, and the operation of the party at lower levels. Clearly a central part of the remit he received from Moscow was to drastically improve

\footnotetext{
${ }^{45}$ AOSPRM, F. 51, inv. 9, d. 3, ff. 92-111.

${ }^{46}$ Sovetskaya Moldaviya, 7 July 1950, 1; Bodiul, Dorogoi zhizni, 50; Dornberg, Brezhnev, 108.

${ }^{47}$ Brezhnev, Vospominaniya, 146.
} 
both the functioning of Moldavian agriculture, and also party control over the countryside. The other issues - propaganda, education, ideology etc. - tended to be addressed by other members of the CC CPM at the plenums. Brezhnev oversaw the implementation of a barrage of initiatives to try and improve the performance of the Moldavian agricultural sector, including diversifying and expanding crop production (tobacco, cotton, sugar beets, grapes, citrus fruits), improving labour discipline, upgrading the work of the MTS [Machine Tractor Stations] and drastically increasing the number of PPO's [Primary Party Organisations] in kolkhozes. Similarly, Brezhnev's most important policy reform in the political sphere was the creation of a new layer of party administration: at the okrug level. When Brezhnev took over in Moldavia, there were only two levels of party administration: republican and city/raion, but he added a new layer. He also worked hard to improve the quantity and quality of agitprop work, most notably by increasing the number of newspapers in rural areas. Finally Brezhnev embarked on the rapid development of Chișinău as a city: the construction of apartment blocks, parks, opera houses and the like. These give us an outline of the main developments of the Brezhnev era. In order to gain some insights into Brezhnev's leadership style, this paper will focus upon the areas that Brezhnev worked most closely upon: the amalgamation of the collective farms and reforms to the party, as well as exploring one of the "darker" moments of Brezhnev's rule, Operation Sever.

\section{The Brezhnevs in Moldavia}

Before we move on to examine his time as party leader, do the Moldavia years throw any light on Brezhnev's private life and personality? We can glean some details from recent memoirs and interviews. On his appointment in June 1950, Leonid Brezhnev came immediately to Chișinău. His wife, Viktoria Petrovna and their daughter Galina joined him. They lived in a house on the Sadovaia Street (now Alexei Mateevici just across the University), less than one $\mathrm{km}$ from the building of the CC. Viktoria Petrovna had however to take care of their home in Dnepropetrovsk too, as their son, Iurii, had just finished school and was starting at the Metallurgical Institute in Dnepropetrovsk. Rita, Viktoria's cousin, was supposed to take care of Iurii and the house, but as she was a student herself and not very fond of being a housekeeper, Brezhnev's wife visited them almost every week, cleaned the house, prepared food for the next week, and then returned to Chișinău. ${ }^{48}$ Here Viktoria Petrovna was busy mainly with housekeeping; she adored as a matter of fact cooking. ${ }^{49}$ As she needed to have

\footnotetext{
${ }^{48}$ Semanov, Brezhnev, 28.

${ }^{49}$ Leonid Brezhnev v vospominaniyakh, razmyshleniakh, suzhdeniyakh (Rostov-na-Donu: Phoenix,
} 
food reserves and keep them in a fresh environment, their house in Chișinău had, supposedly, a cellar. Rumours persist of Brezhnev repeated infidelities, particularly with his female administrative staff, and of children from these encounters, but nothing has ever been proven. ${ }^{50}$

Galina became a student at the Philology Faculty at Chișinău State University. She was not very happy however, as everybody knew whose daughter she was and nobody from her colleagues dared even to talk to her. Supposedly bored, she decided to gather her own company and they drank frequently. Once she and her friends took a taxi to a secret military base in Chişinău, as the guards recognized her and did not want to get into hot water they turned a blind eye. Latterly, her father re-interpreted this action as his intention of seeing how secure the military garrison was, concluding that the guards were impressed with every girl coming to them. ${ }^{51}$

As for Brezhnev himself, he supposedly was a workaholic in this period in contrast to his General Secretaryship after 1964. He went to work at 10 o'clock in the morning and worked till 3 or 4am, sometimes up to 5 o'clock in the morning. And his apparat tried to work as much as he worked. ${ }^{52} \mathrm{He}$ also appears to have been something of a movie lover, often stopping work at midnight on Saturdays and gathering his staff to watch films into the small hours of Sunday morning. ${ }^{53}$ Probably he chose this schedule because it was the usual working pattern of Stalin. It seems however that his workday was indeed very exhausting, as a result he had a heart attack in June 1952 and was hospitalized for several months in various locations, including at the famous high nomenklatura sanatorium in Moscow, Barviha. ${ }^{54}$

Overall though, it is very difficult to get any real insights into Brezhnev's character and personality. The Moldovan newspapers have almost no coverage of Brezhnev as First Secretary. He occasionally appears in print with his name next to an article or in reprinting one of his speeches. But little or no personal items ever penetrate through the archival materials or the press accounts, likely because the focal point was of course Stalin himself. He was, rather ironically, a bit of a grey blur.

1998), 72-73.

${ }^{50}$ Alla Mokhova, Brezhnev's former secretary, in an interview in Komsomol'skaia Pravda, December 19, 2006 for example flatly denied the rumour that Brezhnev was the father of her child, who was born not long after Brezhnev left Chișinău to go to Moscow.

${ }^{51}$ Leonid Brezhnev v vospominaniyakh, 86.

${ }^{52}$ Komsomol'skaia Pravda, December 19, 2006.

${ }^{53}$ Komsomol'skaia Pravda, December 19, 2006.

${ }^{54}$ Mlechin, Brezhnev, 78. 


\section{Brezhnev Takes Over: Reforms to the Party}

How did he set about addressing the tasks set before him by Moscow? Brezhnev immediately embarked on a very energetic programme in the summer of 1950. Like all new leaders, it was important for his authority and credibility to demonstrate some easy "wins" and also psychologically prepare everyone for change. In doing so, he was both confrontational and decisive. His priority in the economic field was to ensure that the state procurement targets for agriculture were met, which he did by mobilising resources (both human and technical) and directing them at the areas where there were lags in the harvest. By August he had over fulfilled the state procurement targets, and set about developing measures for increasing output across a range of different agricultural indicators. ${ }^{55}$ It is also clear that he was the first leader of MSSR that liked to travel a lot into the countryside, to see concretely what were the problems and be informed from unmediated sources, in contrast to his predecessor.

The next issue to be dealt with was the state of the Moldavian communist party itself. The task of upgrading party control had both a quantitative and a qualitative dimension. Brezhnev was keen to improve the quality of work being carried out within the party. This meant working on developing the ideological consciousness of party cadres. Brezhnev embarked on a long round of conferences and meetings with officials, department heads (MTS, kolkhozes) and local party secretaries as they sought to improve the functioning of the apparatus, upgrade the ideological and political levels of party workers and state officials and get the message across that the party officials at lower levels need to be held to account for their actions. ${ }^{56}$ This was in line with a general concern coming down from Moscow that the political and ideological education being carried out was at best second-rate. Proper supervision of economic and cultural life required cadres with a deep knowledge of and engagement with party doctrine.

But there was also a blunter concern over numbers. The party did not have enough of a presence in the countryside, particularly on the kolkhozes. This was seen as a danger sign, especially in the western regions where the issue of infiltration from over the border, or manifestations of nationalist sentiment were deemed to be most likely. This was to be addressed by stepping up the recruitment drive of candidate and full members of the party in rural areas, amongst kolkhoz workers, amongst women and in the west of the republic. It was also to be achieved by consolidating party organisations and having fewer

\footnotetext{
${ }^{55}$ AOSPRM F. 51, inv. 9, d. 25, ff. 7-14.

${ }^{56}$ AOSPRM F. 51, inv. 9, d. 25, ff. 10-12
} 
but bigger party groupings. At a CC CPM buro meeting in December 1950, the shifting pattern of party membership was noted:

- 1 January $1950-1$ November $1950=3404$ candidate members (more than the totals of 1948 and 1949 combined)

- Proportion of peasants and women had increased, and intellectuals and ethnic Moldavians had fallen

- The proportion of party members split between urban and rural areas also shifted:

\begin{tabular}{|l|r|r|r|}
\hline & 1 January 1950 & 1 July 1950 & 1 November 1950 \\
\hline All communists & 25143 & 27073 & 28505 \\
\hline 4 urban areas & $10688(42.5 \%)$ & $10899(40.3 \%)$ & $11312(39.7 \%)$ \\
\hline 60 rural districts & $14455(57.5 \%)$ & $16174(59.7 \%)$ & $17193(60.3 \%)$ \\
\hline
\end{tabular}

Most notable, was the objective of ensuring that every collective farm had a party organisation in situ. On 1 January 1950, there were 17 raions without a kolkhoz party organisation. By November 1950, this had been rectified. ${ }^{57}$

However, the investigation into the internal workings of the party threw up some more contentious issues, and exposed something of a rift between the Moldavian CC and the working practices of the raikoms and gorkoms. In particular by December 1950 Brezhnev was increasingly unhappy with the response of the raikoms and gorkoms to the exhortation to improve the manner of their working. The concern at these working practices emerged as a result of the discussion about violations of "socialist legality" that had been taking place in Moldavia up to 1950 . Brezhnev started an investigation into a variety of violations of socialist legality, which in part at least seems to have been generated by letters and complaints coming to the $\mathrm{CC}$ from members of the public. ${ }^{58}$

In a rather contentious CC buro meeting of 8 December 1950, Brezhnev called the Chief Prosecutor (Osipov) and the head of the Moldovan Ministry of State Security (Mordovets) to account for problems in the area of legality and illegality. ${ }^{59}$ It appears that not only were there significant cases of "embezzlement, theft of socialist property, speculation and hooliganism" going unpunished, but also that the judicial and investigative organs were themselves acting illegally and in violation of the norms of socialist legality. Brezhnev personally and publically ordered both Osipov and Mordovets to, in effect, get their houses in order by rooting out the corrupt officials from within their midst and then renewing the offensive against those truly guilty of violating

\footnotetext{
${ }^{57}$ AOSPRM F. 51, inv. 9, d. 29, ff. 65-78.

${ }^{58}$ AOSPRM F. 51, inv. 9, d. 22. ff. 7-22 and 31-37.

${ }^{59}$ AOSPRM F. 51, inv. 9, d. 22. ff. 9-15.
} 
the norms of socialist legality. Brezhnev demonstrated a resolute determination to address this issue and directly confronted the heads of the judicial and investigative organs and to hold them to account, interestingly using the complaints and protests of the people as part of his rationale. ${ }^{60}$ The seeming unwillingness of Koval to address this issue must account in part for Brezhnev's determination to face down Osipov and Mordovets.

However his analysis of the causes of this situation took him beyond the personal failings of the leaders of these two arms of the Moldavian judicial apparatus. Brezhnev also clearly saw it as a failing on the part of the lower levels of the party hierarchy. His diagnosis of the problem was that too much of a gap had occurred between the party organs and the judicial organs, and the former had insufficiently controlled the actions of the latter, and had not done enough to disseminate the party line amongst militia, prosecutors, investigators and the like. Brezhnev affirmed that the raikoms and gorkoms needed to work harder in terms of the selection and training of cadres, in verifiying that party directives were being carried out, in overseeing the activities of all the PPOs in their jurisdiction. Brezhnev was clearly intent on making the party - at both raikom/ gorkom and CC level - more accountable for their actions and also to take the ideological/political side of their duties seriously. ${ }^{61}$

A good example of the sort of scrutiny that Brezhnev imposed on the operation of the raikoms and gorkoms was his review of the party exclusions and punishments carried out prior to his arrival in Moldavia. ${ }^{62}$ Brezhnev had 235 cases of exclusion from the party re-examined. 4 of these were abolished. 53 communists had their sanction downgraded from exclusion to punishment/sanction, usually a dressing-down or severe reprimand. In 178 cases, the decision to exclude was upheld. From the limited number of case files reviewed, the decision to uphold exclusion from the party was more to do with prior conduct (especially during the war) or concealment of something considered "dangerous" in their background, than more recent problems around abuse, theft, or drunkenness/inappropriate behaviour, although these were still grounds for exclusion. Some of the case files concerned individuals who supported or failed to oppose the occupying Axis forces during the war. These case reviews tend to support the views of Amir Wiener, Sheila Fitzpatrick and others who have looked at the shifting patterns of exclusion and inclusion in the post-war Soviet body politic. In constructing a new basis for Soviet socialist social harmony, conduct in the war, ethnic loyalties, and/

${ }^{60}$ Resolution of the CC PCM buro of 8 December 1950: AOSPRM F. 51, inv. 9, d. 22. ff. 34-37.

${ }^{61}$ AOSPRM F. 51, inv. 9, d. 22, ff. 13-20.

${ }^{62}$ AOSPRM F. 51, inv. 9, d. 6, ff. 169 - 187 
or evidence of personal social depravity (drunkenness, theft of state property, other miscellaneous work-place abuses) became key markers for the regime in deciding who was "in" or "out" ${ }^{63}$ These tended to augment previous criteria for social categorisation (especially class background or "unhealthy" associations), which had prevailed in the 1930s. What is interesting is that these previous categories did not disappear altogether of course. Evidence of "kulakite" tendencies could also lead to exclusion, as the process of collectivization was still proceeding apace in Moldavia. This reinforces the idea that Moldavia was experiencing simultaneous transformations: Sovietization and post-war reStalinization.

In reducing or overturning the decisions, the conclusion drawn by Brezhnev was that raikom and gorkoms had shown an "unserious" approach to this question, and he imposed on them the requirement to review any such cases in their jurisdiction and provide a remission of sanctions where necessary. ${ }^{64}$ Clearly Brezhnev was taking a very hands-on approach to the oversight of the lower-level party bodies, and was keen to create a greater sense of predictability for party members by ensuring that the proper processes for regulating internal party life were being followed. Again we see Brezhnev motivated by the need to address the shortcomings of his predecessor, and drill down into what was happening in the party at local levels. He had to demonstrate, particularly to Malenkov to whom he appears to have been reporting in the first few months, due diligence in his stewardship of the party. The deeper conclusion drawn by Brezhnev was the need to monitor and supervise much more closely the work of lower-level party organs. This led to his most wide-reaching reform: the institution of an okrug level of party organisation. Brezhnev added another layer by dividing Moldavia up into 5 territorial okrugs, each with their own bureaucratic structures and apparatus. These okrug level structures took a deal of power away from the lower levels, and were also there to ensure the lowest levels were accountable for their actions. The idea behind it was that these 5 okrug committees would be responsible for supervising the implementation of central directives (in the areas of economic development and cultural construction), something which had proven to be beyond the republican level committees, and also to oversee the training and deployment of cadres. ${ }^{65}$

${ }^{63}$ See Fitzpatrick, Late Stalinism; Weiner, Landscaping; Harrison, The Soviet Union After 1945.

${ }^{64}$ AOSPRM F. 51, inv. 9, d. 6, ff. 180-182.

${ }^{65}$ This reform was heavily criticised by Bodiul, Dorogoi zhizni, 58-61. Brezhnev outlined his plans most fully in his report to the $5^{\text {th }}$ plenum of the CC PCM. AOSPRM F. 51, inv.11, d. 6, ff. 55-58. 


\section{Amalgamating the kolkhozes}

The state of agriculture was a constant cause for concern for Moscow after the war. Reasserting party control over the rural areas was critical for a number of reasons. Restoring and increasing grain supplies was vital to the reconstruction effort. Politically, restoring party control and authority was probably even more pressing. Undertaking a rapid collectivisation in the newly acquired western territories plus reviving the collective farms in areas which had been subject to Axis occupation were seen as crucial in driving out semi-private farming and also giving the party a firm foothold amongst that section of the population deemed - along with the national intelligentsia - to be most hostile to Soviet rule. ${ }^{66}$ In particular, the party seem to have been concerned with peasants who had been able to evade state control by existing on isolated farms a long way away from towns or villages. A series of All-Union CC plenums in 1947/48 attempted to address the problems in Soviet agriculture, including prohibiting theft and illegal activities and improving labour discipline. ${ }^{67}$ Brezhnev's appointment to Moldavia coincided with a major central initiative in the first half of 1950: the decision to undertake a thoroughgoing amalgamation of smaller kolkhozes into fewer but larger ones. This was to improve efficiency and open the way for increased mechanization. Details of this plan were provided in a CC VKP (b) resolution of May 1950. When Brezhnev turned up in Moldavia just over a month later, this was to be a priority.

Brezhnev initiated the campaign to implement this key directive. The initial rationale he provided for the amalgamation of small kolkhozes was to create opportunities for mechanisation, to raise the productivity of labour, to ensure the all-round development of kolkhoz activity and improve the welfare and cultural level of the kolkhoz peasantry. But Brezhnev was aware of the potential to turn this into a campaign which had a dual aim: to satisfy Moscow that he was a "doer": he could realise the policy directives sent down from above, and secondly it could, if handled correctly, be a means of generating positive publicity for himself. ${ }^{68}$ The campaign to strengthen and amalgamate the kolkhozes in Moldavia got underway in earnest in 1951. Over 2000 kolkhozes existed in July 1950, but they had been reduced to 508 by 1952. Brezhnev not only stressed the implementation of this policy, but also went on to highlight that as a result of these reforms, many kolkhozes now had incomes in excess of 1 million rubles. ${ }^{69}$ In other words, Brezhnev's reforms had more than doubled

${ }^{66}$ For background see Gribincea, Agricultural Collectivization; and Boterbloem, Life and Death.

${ }^{67}$ Boterbloem, Life and Death, ch. 7.

${ }^{68}$ Bodiul, Dorogoi zhizni, 53-56.

${ }^{69}$ Brezhnev talked about these things at length in both his 1951 report to the $7^{\text {th }}$ plenum of the CC 
the number of millionaire kolkhozes! Now this of course was little more than an accountant's sleight of hand. It was the result of adding the incomes together. But it was always skilfully (and endlessly) trumpeted as evidence of the beneficial results of Brezhnev's time in power. Moldavian newspapers were full of stories of these prosperous kolkhozes. ${ }^{70}$ In reality, according to Bodiul, the performance of the kolkhozes at this time remained dogged with problems: low labour productivity, low levels of mechanisation, disorganised work brigades, an absence of leaders and too few experts. In fact this reform actually exacerbated the problems in the kolkhozes. The larger farms received resources designated for some of the smaller farms and villages, which left the latter without machinery and investment to help them grow. ${ }^{71}$ This led to a good deal of resentment in certain areas at the diversion of resources. Secondly, the amalgamation of the kolkhozes actually undermined the internal cohesion and operation of the farms. The growth in size complicated the management process, disrupted mechanisation and generally led to disorganisation which had a detrimental effect on output. The continued existence of problems was easily explained away by "deficiencies in the leadership of agriculture" both within the kolkhozes but also within the ministry of agriculture. Someone lower down could always be blamed. ${ }^{72}$

This was a classic example of the tendency for Brezhnev (along with other leaders) to focus on the mechanistic fulfilment of a directive and the creation of an opportunity for favourable publicity over the intent and aim of the original directive. This was a problem deeply embedded in the command-administrative system. Moscow had provided the resources and had initiated the campaign. Brezhnev undertook the necessary reforms and triumphantly announced the creation of "millionaire kolkhozes". Propaganda campaigns spread the good news. Similar processes can be seen in the procurement campaigns which were undertaken to raise the output levels on various farms. Resources - both human and animal - were rapidly mobilised to meet the targets sent down from above. Once the target was met, everything reverted back to normal, and it was left to the local leaders to pick up the pieces and cope with the disruption. ${ }^{73}$

PCM in January 1951, and the report to the $5^{\text {th }}$ plenum of the CC PCM in January 1952. See AOSPRM F. 51, inv. 10, d. 3, ff. 1-42 and AOSPRM F. 51, inv. 11, d. 6, ff. 40-45.

${ }^{70}$ The pages of Sovetskaya Moldaviya are full of these reports during 1951 and 1952.

${ }^{71}$ Bodiul, Dorogoi zhizni, 54.

${ }^{72}$ Brezhnev continued to peddle this line in his speeches. See AOSPRM F.51, inv. 10, d. 3, ff. 23 25.

${ }^{73}$ In his reports to the CC Brezhnev constantly stressed the importance of meeting targets, upgrading work discipline and practices and the need to hold people accountable for when work was not completed. A litany of kolkhozes and raikoms were mentioned (as both positive 
Brezhnev's priorities were short-term, his focus on energetically achieving the targets sent down from above. In this regard Brezhnev displayed himself to be a consummate politician of the Soviet-type, seamlessly weaving together his own agenda with that of the centre, publicising his successes and glossing over the accumulating problems.

\section{Operation Sever}

Successfully fulfilling central directives was obviously a crucial part of the tasks of the First Secretary. Brezhnev had to oversee just such a campaign in Moldavia in the spring of 1951. In the early morning of April 1951, the state security ministry in Moldavia undertook its part of Operation North (Sever) which was the campaign to deport Jehovah's Witnesses (JWs) from the Soviet West into Tomsk and Irkutsk regions of Siberia. ${ }^{74}$ Operation Sever was initiated because the JW's were classified as being anti-Soviet. This group was a new one for the USSR, as prior to WWII there had been hardly any JWs, and it was with the annexation of the Baltic states and Moldavia (along with some in Ukraine and Belorussia) that the USSR "acquired" this new religious sect. Moscow identified over 8000 people from 6 different republics - Estonia, Latvia, Lithuania, Belorussia, Ukraine and Moldavia - listed for resettlement. Most of those designated came from Ukraine and Moldavia (Bessarabia and Northern Bukovina). 3 March 1951 saw a decree issued by the USSR Council of Minsters, followed by a MGB decree 2 days later.

The documents from the Moldovan MGB archives detail the progress of the action. The Moldavian part of the operation began in earnest on 10 March $1951 .^{75}$ A report on the activities of the JWs was circulated. This stressed the linkages with JW headquarters in New York, and described a highly centralised movement which operated theocratic schools where adherents were trained. The anti-Soviet nature of the JWs was highlighted in the following ways:

- disseminating provocative views, especially about the inevitable downfall of Soviet power and the establishment of a theocratic government.

- refusal to take part in obligatory state activities, eg. military service

and negative examples) in his addresses to the party. See the 1951 and 1952 CC PCM plenum reports as good examples of this: AOSPRM F.51, inv.10, d.3, and AOSPRM F.51, inv.11, d. 6.

${ }^{74}$ Background and more details on the treatment of JWs in the USSR can be found in, Emily Baran, Dissent on the Margins: How Soviet Jehovah's Witnesses Defied Communism and Lived to Preach About It (Oxford: Oxford University Press, 2014).

${ }^{75}$ ASISRM-KGB [Archive of Security and Intelligence Service of the Republic of Moldova (former KGB)]. Delo po operatsii Sever “Spravka: O sekte iyegovistov" 10 March 1951. 
- anti-Soviet agitation against collective farms

- refusal to participate in elections and agitation amongst youth to get them to refuse to participate in socio-political organisations. ${ }^{76}$

There were several different aspects to the their 'antiSovietness' which must have been of concern to the Soviet authorities. Not only were their religious beliefs and activities deemed to be hostile and dangerous, but their connection to Western religious groupings just as the Cold War was becoming intense must have also been alarming. ${ }^{77}$ On March 24 the Moldavian Council of Ministers issued a decree confiscating their property, and the MGB sent round the orders for how to organise and co-ordinate the action across 14 different areas and 753 family groups. At 4 am on 1 April 1951, the "resettlements" began. A total of 1127 MGB personnel took part (assisted by 275 militia and 750 party aktiv). It finished at $8 \mathrm{pm}$ the same day. The report of the Moldavian MGB was sent directly to the notorious Viktor Abakumov, the head of the All-Union MGB, from Iosif Mordovets. ${ }^{78}$

The implementation of Operation Sever while on Brezhnev's watch was a reminder of both the constant presence of the centre in the lives of the republics, and of the ongoing and problematic nature of the process of Sovietisation in the western republics of the USSR. Vigilance was constantly required on the western border, and Brezhnev's time in Moldavia was invaluable experience for him of governing in the Soviet West and of the particular issues caused by “anti-Soviet' groups. But Brezhnev's actions with regard to deportations and treatment of the "enemies of the people" also give us some insights into his own priorities. Typical for the local leaders of the party, Brezhnev also displayed, on at least one occasion in Moldavia, what one might term "excessive zeal" in the campaign against the 'enemies of the people'. On March 16 1951, he sent a request to Moscow asking that a supplementary deportation be organized for persons who had avoided for one or another reason the mass deportation of July 1949 (more than 3120 persons). For certain unknown reasons, Moscow did not endorse Brezhnev's proposal. The idea was however discussed a year later on May 281952 by the Collegium of the MVD of the USSR and latterly on June $101952 .{ }^{79}$ The solution adopted in this case was to tax double the families

${ }^{76}$ Delo po operatsii Sever, ff. 1-4.

${ }^{77}$ A similar case in nearby has recently been revealed by Hiroaki Kuromiya, Conscience on Trial: The Fate of Fourteen Pacifists in Stalin's Ukraine, 1952-1953 (Toronto: University of Toronto Press, 2012). This case was about Seventh Day Adventists rather than JWs.

${ }^{78}$ ASISRM-KGB, Delo po operatsii Sever “Dokladnaya zapiska” 4 April, 1951, ff. 1-5.

${ }^{79}$ Istoria Stalinskogo Gulaga, vol. 5, 'Spetspereselentsy v SSSR' (Moskva: ROSSPEN, 2004), 677$678,686$. 
and persons that avoided the deportation in July 1949 instead of sending them to Siberia. ${ }^{80}$ The same situation seems to have prevailed in other parts of 'Molotov-Ribbentrop Europe' as Timothy Snyder has termed the territories occupied by the Soviet Union between September 1939 and June 1940, ${ }^{81}$ i.e. Western Ukraine, Western Byelorussia, Lithuania, Latvia and Estonia. ${ }^{82}$ During Brezhnev's rule in Moldavia there were also liquidated the last armed anti-Soviet groups and in this sense he managed to fulfill another objective when he was appointed to the Moldavian SSR in $1950 .{ }^{83}$

\section{Brezhnev As Party Leader}

Brezhnev's time in Moldavia was brief, and much of it was spent dealing with two issues: agriculture and the party. What do his addresses to CC $\mathrm{CPM}$ plenums and Congresses tell us, if anything, about his leadership of the Party? Brezhnev's address at his inaugural meeting to the CC CPM buro focused primarily on the state of affairs in the countryside, reflecting the concerns of Moscow. The need for closer control of rural affairs, and greater efficiency in the countryside stemmed from this dual anxiety over nationalism/ opposition and economic reconstruction. Brezhnev set out the need for harder work by the party in the countryside to improve productivity and also to complete collectivization. ${ }^{84}$ His first major set-piece speech was the one which commemorated the $10^{\text {th }}$ anniversary of the formation of Soviet Moldavia. It was all standard fare, celebrating the great successes in industry, agriculture and education, and lauding the great Stalin for liberating the Moldavian people from the bondage of imperialism. ${ }^{85}$ Behind the scenes, Brezhnev was corresponding with Georgii Malenkov about his progress in achieving the objectives that Moscow had set, most notably in organizing meeting with secretaries of raikoms, and gorkoms, procuring the harvest, and in particular with confirming nomenklatura appointments. Brezhnev was at pains to stress that he had personally interviewed the new chairmen of the amalgamated kolkhozes, reinforcing the importance of this latest initiative for both the centre and the local leader. It must also have been a reminder of the delicate balance of power in Moscow, and of the need to remain vigilant.

${ }^{80}$ Vladimir Tsaranov, 'O likvidatsii kulachestva v Moldavii letom 1949 goda', Otechestvennaia istoriia, 2 (1996), 78.

${ }^{81}$ Timothy Snyder, Bloodlands. Europe Between Hitler and Stalin (New York: Basic Books, 2010), ch. 4.

82 Pasat, RSS Moldovenească, 360-361.

${ }^{83}$ See Elena Postică, Rezistența anti-Sovietică în Basarabia, 1944-1950 (Chişinău: Știința, 1997).

${ }^{84}$ Stenogram of meeting of CC 8 July 1950 in AOSPRM F. 51, inv. 9, d. 23, ff. 58-63

${ }^{85}$ Sovetskaya Moldaviya, 18 August, 1950, 1. 
In his CC CPM plenum speeches, Brezhnev was not slow to raise problems and criticisms of the performance of his subordinates. In the speech made on 26 January 1951, he compared the agricultural performance in 2 (named) raions and posed the question: why is one underperforming? The answer was labour discipline, and problems with the performance of the respective cadres. This required greater agitprop work, and also a change of attitude. Kolkhoz workers needed to be more positive and optimistic about the future, and party workers must know the attitudes and feelings of the people in their locality. In his January1952 report to the $5^{\text {th }}$ plenum of the CC PCM, Brezhnev outlined the deep flaws in the work of the raikoms and raispolkoms, as part of his campaign to introduce the okrug level of administrative oversight. He named specific raions and their secretaries, noting serious failings and problems, and observing that "a characteristic trait in the work of the raikom is belief in the miraculous power of directives and decisions". ${ }^{86}$ This practice of explicitly naming poorly performing districts and individuals was continued in his March 1951 Congress speech, highlighting the failures of the now sacked Minister of Trade (Akimov) for example. ${ }^{87}$ Brezhnev also addressed the questions of language and national identity, bemoaning the lack of propaganda available in the Moldavian language, and also mentioning the deficiencies in the education system which was making it difficult to eradicate the "remnants of bourgeois ideology" ${ }^{88}$ By the time of his speech to the $4^{\text {th }}$ Congress in September 1952, the task of deepening Moldavia's Sovietisation was to pass to Brezhnev's successor, as he had been called to Moscow to serve there.

\section{Exit Moscow}

Brezhnev obviously did an excellent job in conveying an image of a dynamic First Secretary who was able to achieve the tasks set before him by Moscow, improve the operation of Moldavian agriculture and deepen party control and presence in the Moldavian countryside. He worked hard to ensure that Moldavian successes were trumpeted on the pages of Pravda, with all the appropriate gratitude to Stalin accompanying it. ${ }^{89}$ He kept in regular contact with Malenkov and others in Moscow, informing them of developments,

${ }^{86}$ Brezhnev's Political Report to the PCM CC 25 January 1952, AOSPRM F. 51, inv. 11, d. 6, f. 52.

${ }^{87}$ Brezhnev's speech to the $3^{\text {rd }}$ PCM Congress 30 March 195, AOSPRM F. 51, inv. 10, d. 1, ff. 6869.

${ }^{88}$ AOSPRM F. 51, inv. 10, d. 1, f. 70

${ }^{89}$ There are 2 or 3 notes from Brezhnev about tremendous agricultural successes as well as information about progress coming from CC CPM plenary meetings. See for example Pravda, September 14, 1951, 2 and March 3, 1952, 3. 
of progress in certain areas. He was rewarded on $16^{\text {th }}$ October 1952 when he was selected by Stalin, at the $19^{\text {th }}$ Party Congress, to join the new Central Committee. He also subsequently became one of the candidate members of the new Praesidium, and one of the 10 CC Secretaries. Although he remained a member of the buro of the Moldavian CC until June 1953, he moved immediately to Moscow. In the reorganisation that followed Stalin's death Brezhnev was demoted out of both the CC and Secretariat. He was appointed first deputy head of the political administration of the new Ministry of Defence. He was however able to retain close ties to Khrushchev which was to save his career and open the way for a rapid advance once Khrushchev became more influential within the party.

However, although it may seem that Brezhnev's move from Chișinău to Moscow was swift and untroubled, this is not quite the full story. The 4th CPM Congress of September 1952 was a rather stormy affair in which Brezhnev was criticised from the floor, and the criticisms of him were reported in Pravda. Most of the criticisms of him related to the okrug party reforms and to personnel issues..$^{90}$ One Pravda report noted that,

It should be added that such a statement in Comrade Brezhnev's report as: "We members of the bureau have tried to conduct plenary sessions trenchantly, not sparing our leaders' feelings and holding them to a high-principled level" caused bewilderment. The speeches of those delegates who criticized some members of the Central Committee and some members of the bureau of the Moldavian Party Central Committee indicated that the assertions in the report did not reflect the true state of affairs...."Such errors on the part of the Moldavian Party Central Committee," said Comrade Forsh, Secretary of the Kagul Region Party Committee, "are due to the Party Central Committee departments' inadequate knowledge of local personnel. ${ }^{91}$

Brezhnev was responding to criticisms of Lazarev (one of the secretaries of the CC and Minister of Culture) who was apparently responsible for personnel errors in the ideological field. Brezhnev decided to defend Lazarev, which clearly rankled with many in the party, who spoke out very boldly and critically. Clearly, Brezhnev's time in power had evoked strong feelings amongst the lower ranks of the CPM. The criticisms of him implied that Brezhnev's rhetoric and his practice did not line up very well, that the creation of the okrug committees meant that Chișinău took little interest in what was going at raion level, and also hinted at Brezhnev's willingness to defend his allies in the face

${ }^{90}$ Cited in Leo Gruliow ed., Current Soviet Policies: The Documentary Record of the $19^{\text {th }}$ Communist party Congress and the Reorganization After Stalin's Death (New York: Praeger, 1953), 83.

${ }^{91}$ Gruliow, Current Soviet Policies, 83. 
of opposition and criticism. Brezhnev was accused of favouritism, recruitment errors and glossing over his mistakes. Murphy contends that this campaign of criticism against Brezhnev was orchestrated by Malenkov, who was trying to discredit Khrushchev by discrediting Brezhnev. Brezhnev was forced to take to the pages of Bolshevik (the party theoretical organ) to defend his record. ${ }^{92}$ In spite of these very public criticisms, Brezhnev was able to ride out this storm and his promotion to Moscow went through the next month.

The naming of Brezhnev's successor was also an interesting development. According to Pasat, the choice of Dmitri Gladki (October 25, 1952 - February $7,1954)$ as his successor was done very deliberately. Brezhnev nominated a very weak leader as his heir in order to make his time in Moldavia look as good as possible in the eyes of both the local nomenklatura and people, as well as in the eyes of the Centre. Brezhnev was always working on his reputation. ${ }^{93}$

\section{Conclusion: Brezhnev as First Secretary}

Governing Soviet Moldavia was clearly beneficial to Brezhnev's career. He gained invaluable experience of the problems of collectivization and Soviet agriculture, had to confront issues pertaining to Moldo-Romanian nationalism and language issues, had to deal with a complex process of elite recruitment and oversaw a small-scale repressive action against an anti-Soviet religious sect. He was successful enough (or at least able to portray a picture of success) to convince those higher up that he could be trusted with responsibility at the All-Union level, even given the levels of criticism directed at him in September 1952, which tends to suggest that he had good connections and protection higher up. He also continued the practice of identifying and developing close links with reliable political lieutenants which was to stand him in good stead when he became General Secretary, especially Konstantin Chernenko, whom he brought to Moscow in 1956, Sergei Trapeznikov, Semyon Tsvigun and Nikolai Shchelokov. Finally Brezhnev developed a fine appreciation of the pressures that regional and provincial leaders were under, and this must have helped him develop an empathy and understanding with them when he became General Secretary, especially in avoiding much of the arbitrariness with which Khrushchev operated in this regard.

What does Brezhnev's time in Soviet Moldavia tell us about his leadership qualities and style? Brezhnev acted as a zealous implementer of central initiatives. He worked hard to establish party control in the rural areas and strengthen the collective farms. He resolutely campaigned against nationalism

\footnotetext{
${ }^{92}$ Murphy, Brezhnev, 120-23.

93 Pasat, RSS Moldovenească,181-183
} 
in language, literature and history. His time in Moldavia bears witness to a Brezhnev who was an adept player of the "game" of Soviet elite politics, a man who was able to grasp the opportunity afforded to him and keep propelling himself up the ladder towards Moscow. Leonid Mlechin notes that while Brezhnev was not a cruel or malicious character, he exhibited the same studied indifference to the suffering of those around him that was common amongst members of the apparat. ${ }^{94}$ Clearly the fact that Moldavia was a temporary staging-post in Brezhnev's journey to Moscow means that he could focus very much on achieving a very narrow set of objectives: implement central initiatives, create a good impression, keep his superiors informed, proclaim his triumphs, and (hopefully) move on. He was an adept publicist. He also showed the uncanny ability to prioritise tasks and sift through to achieve the things that he needed to do, and at the same time downplay those elements which might have proven more problematic or complex to implement. The case of amalgamating kolkhozes springs to mind here: an administrative change with significant visual impact, but one which left untouched the deeper issues of labour productivity, mechanisation and labour discipline on the collective farms. He also seemed to take seriously the views and opinions of party members who wrote to the $\mathrm{CC}$, and was willing to publicise and promote those who undertook successful work which could be emulated by others. This suggests perhaps a desire to cultivate a positive reputation amongst the party rank and file as well as with his superiors. He appears to have been a leader who cultivated and valued loyalty.

Brezhnev showed himself to be a leader of some energy, decisiveness and responsiveness. This is not unexpected given that he was 43 when he turned up in Moldavia. Although Brezhnev was around in Soviet Moldavia for only 26 months, it was a very busy time. He undertook a series of policy initiatives and reforms across a range of fields, most notably agriculture (including the organisation and structure of the collective farm sector, mechanisation, output and crop diversity), industrial development, improvement of agitprop work (especially amongst the Moldavian youth), enhancing the ideological training of cadres, increasing the party's presence in the countryside and also reconfiguring the party's organisational structure. Given the rather dominant image of the shuffling, infirm, aged figure of the late 1970s and early 1980s it is worth mentioning that a brief glance at Brezhnev's pre-1964 career gives us a completely different viewpoint. He can, rightly perhaps, be criticised for pursuing a set of policy priorities which were essentially short-termist and

${ }^{94}$ Mlechin, Brezhnev, 90. 
designed to meet the interests of Moscow (and also himself) at the expense of the people of Moldavia. Very few, if any, of his policy initiatives left the Moldavian republic stronger, or benefited the people. But this is really a result of the pressures produced by the system, and it is unrealistic to expect Brezhnev to have acted otherwise, given the remit he was handed in July 1950.

During his time in Moldavia he was also unafraid to confront fellow leaders and hold them to account, even powerful figures such as Mordovets. He does not come across as a grey, cautious figure, unwilling to deal with colleagues who are out of line. But at the same time, he seems not to have been a dictatorial first secretary either. Brezhnev emerges as a leader with a well-developed understanding of the importance of creating a political climate which reduced arbitrariness, and which combined accountability with opportunities for people to change. Although mistakes and problems were highlighted, individuals would have the chance to put them right (e.g. Osipov and Mordovets). Brezhnev would defend those coming under attack (Lazarev), if they were perceived to be loyal. He sought to develop a sense of regularity and procedure which meant that people at all levels of the hierarchy knew what was expected of them. His review of party expulsions - in which he overturned or downgraded over $20 \%$ of the cases he reviewed - suggests a leader concerned that people should not be punished or sanctioned without due reason, and that sanctions should not be seen as final.

Finally Brezhnev's time in Soviet Moldavia in many ways embodies something of the evolving nature of the Soviet system by 1950 . He was, of course, a Party man to the core. His approach reflects many of the long-standing Bolshevik concerns and values. The stress laid on cadres and the importance of the right people having the right ideological education and consciousness if the party was to succeed is a classical Leninist modus operandi. Vanguard thinking runs throughout Brezhnev's leadership. He also defaulted to solutions which favoured quantity over quality. Increasing party control over rural areas could best be achieved by recruiting more people for the party in those areas. His rule also expresses the post-war priorities of the Soviet system: improving agriculture, completing Sovietisation, eliminating nationalism, purging dissent. Yet although his thinking and action bears the imprint of the Bolshevik mindset and world-view, he also points forward to the post-Stalin era, in which the politics of the USSR would be more complex, more collegial, more measured. Brezhnev's approach to the exercise of power - in particular his treatment of colleagues, superiors and subordinates - suggests someone with an intuitive feel for the relational dimensions of power. However, his instinctive preference for those policies which looked good also reminds us of the inherent problems 
of the Soviet system: it was a system which rewarded those who worked to preserve and maintain it, not those who wished to change and reform it. In this sense this study of Brezhnev's early years helps us to understand both why he rose to the top, and why the system had accumulated so many problems by the time he died.

\section{Rezumat}

Cuvinte-cheie: Brejnev, RSS Moldovenească, teritorii vestice de frontieră, Basarabia, Transnistria, Nicolae Coval, colectivizare, consolidarea colhozurilor

Articol reprezintă prima încercare sistematică de a analiza episodul moldovenesc din cariera lui Leonid Brejnev. Documentarea este întemeiată atât pe numeroase memorii care ating tangențial și anii 1950-1952, cât și mai ales pe documente de arhivă care provin din Arhiva Organizațiilor Social-Politice a Republicii Moldova, fosta arhivă a Institului de Istorie a Partidului de pe lângă Comitetul Central al Partidului Comunist al Moldovei. Autorii încearcă să înțeleagă importanța perioadei în care Brejnev s-a aflat în RSS Moldovenească (1950-52) în calitate de prim-secretar al CC al PC(b)M pentru cariera sa ulterioară. În vederea înțelegerii mai bune a impactului pe care l-a avut perioada din RSSM asupra lui Brejnev și a stilului său de conducere, autorii discută cariera sa anterioară, precum și cea a celorlalți primi-secretari ai CC ai PC(b)M. Unul din principalele rezultate ale perioadei lui Brejnev în Moldova a fost consolidarea colhozurilor. O trăsătură distinctă a aflării sale în Moldova a fost introducerea unui stil personal de comunicare cu sublaternii, mai relaxat decât cel al predecesorilor, dar şi al urmaşilor săi la conducerea CC al PCM. În sens mai larg, încă din această perioadă, cel puțin, Brejnev favoriza cantitatea asupra calității. Pe de altă parte, autorii evidențiază și faptul că activitatea lui Brejnev în Moldova a fost determinată în linii mari de obiectivele pe care i le-a trasat Moscova atunci când a fost numit la Chișinău. 